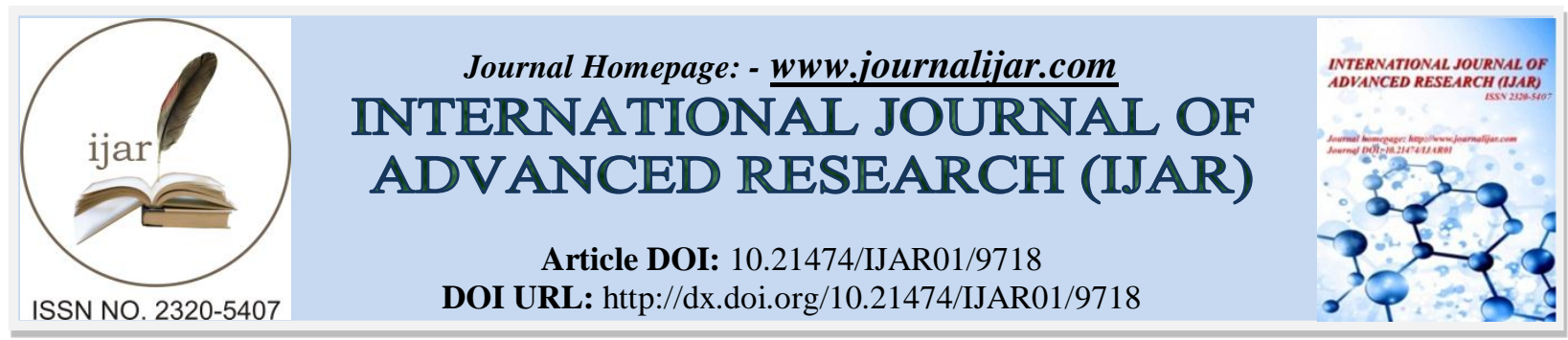

RESEARCH ARTICLE

\title{
EFFECT OF RHIZOBACTERIA AND ARBUSCULAR MYCORRIZHAL (MA) ON GROWTH OF POTATO (SOLANUM TUBEROSUM L).
}

\author{
Weni Veriani ${ }^{1}$, Indra Dwipa ${ }^{2}, Z_{\text {Zul }} \operatorname{Irfan}^{3}$ and Warnita ${ }^{2}$.
}

1. Post Graduate of Magister of Agronomy, Department of Agronomy, Faculty of Agriculture, Andalas University, Padang, West Sumatera Indonesia.

2. Lecturer, Department of Agronomy, Faculty of Agriculture, Andalas University, Padang, Indonesia.

3. Researcher, Balai Pengkajian Tekmologi Pertanian of West Sumatera, Solok, West Sumatera, Indonesia.

\section{Manuscript Info}

(.........................

Manuscript History

Received: 09 July 2019

Final Accepted: 12 August 2019

Published: September 2019

Key words:-

Arbuscular mycorrhizal, potato, rhizobacteria.

\section{Abstract}

Potato is main staple food in several region of the world. The research aimed to study the effect of rhizobacteria and arbuscular mychorrizal to potato growth.The research was conducted in Balai Pengkajian Teknologi Sumatera Barat (BPTP) and Laboratory of Microbiology, Faculty of Agriculture, Andals University, West Sumatera, Indonesia from October 2017 to May 2018West Sumatera, Indonesia. The factorial design in randomized block design (RBD) was used in the assay. The first factor was rhizobacteria isolates and second factor was arbuscular mychorrhizal (AM). The rhizobacteria isolates were no rhizobacteria, RZ1.L2.4, RZ1.L2.1, RZ2.L2.1. The AM doses were 5 $\mathrm{g} / \mathrm{plant}, 10 \mathrm{~g} / \mathrm{plant}$ and $15 \mathrm{~g} / \mathrm{plant}$. The result showed that he best treatment was RZ2.L2.1 and $5 \mathrm{~g} /$ plant of MA dose for potato growth.

\section{Introduction:-}

Potato is staple food together with rice, sorghum and corn [1]. It is one of horticultural commodities that plays role as carbohydrate source and raw material for various food including vegetable and snacks. Potato contains high carbohydrate content and this plant can be used carbohydrate source replacing rice for diabetics [2]. Potato also contributes the economic development due to it is intensively cultivated by many farmers and absorbing many employees.

The main problem that faced by Indoesia goverment in potato cultivation is low production. As a comparison, the potato productivity per hectare in Australia is 39.69 ton, United States 47.15 ton, Japan 30 ton and Laos 30.04 ton [3]. To solve this problem, many ways can be used and one of them is rhizobacteria and mycorrhizal application [4][5]. Rhizobacteria is bacteria that lives in root zone and plays role as plant promoting. This ability is known as Plant Promoting Rhizobacteria (PGPR). PGPR was reported it could increase the growth and yield of potato [6]. PGPR also incrased the plant resistance to pest and disease [7]. Rhizobacateria could be isolated from many plants such as cabbage, apple, soybean and graminae plant [8][9]. In graminae plant, Azotobacter paspali, Pesudomonas sp. and Beijerinckia sp. Azotobacter were reported to play role as N2 fixer bacteria that can produce gibberellin, cytokinin and indole acetic acid, the compounds can stimulate root growth [10].

Corresponding Author:-Weni Veriani.

Address:-Post Graduate of Magister of Agronomy, Department of Agronomy, Faculty of Agriculture, Andalas University, Padang, West Sumatera Indonesia. 
The other way to increase the growth and yield of plant, several researches reported the mycorrhizal arbuscular can be used [11]. Mycorrhizal arbuscular (MA) is a system that is formed as manifestation of mutualism symbiotic between fungi (myces) and roots (rhiza) of higher level plants [12]. Interaction between rhizobacteria and MA is not widely reported. The interaction of these can be applied to increase growth and yield of potato in Indonesia. The research aimed to study the interaction between rhizobacteria and MA in increasing the growth and yield of potato.

\section{Material and method:-}

The research was conducted in Balai Pengkajian Teknologi Sumatera Barat (BPTP) and Laboratory of Microbiology, Faculty of Agriculture, Andals University, West Sumatera, Indonesia from October 2017 to May 2018West Sumatera, Indonesia. The materials used in the assay were seed potato variety Granola, Rhizobacteria isolates. MA isolates, water, labels, plastic, envelopes, manure, lime, NPK fertilizer.

The factorial design in randomized block design (RBD) was used in the assay. The first factor was rhizobacteria isolates :

1. R0 : no rhizobacteria

2. $\mathrm{R} 1$ : RZ1.L2.4

3. $\mathrm{R} 2:$ RZ1.L2.1

4. R3 : RZ2.L2.1

The second factor was Mycorrhizal arbuscular (MA)dose :

1. $\mathrm{M} 1: 5 \mathrm{~g} / \mathrm{plant}$

2. $\mathrm{M} 2: 10 \mathrm{~g} / \mathrm{plant}$

3. $\mathrm{M} 3: 15 \mathrm{~g} / \mathrm{plant}$

The treatments were replied 3 times. The data was analysed by analysis of variance and followed by Duncan's New Multiple Range Test in $5 \%$.

\section{Result and discussion:- \\ Percentage of root infection}

The interaction between rhizobacteria and MA did not affect the percentage of root infection (Table 1). The result was similar to the previous report that reported the root infection in Jabon (Anthocephalus cadamba (Roxb.) Miq) was $0.71 \%$ and $10 \%$. The infection $0.71 \%$ was obtained from rhizobacteria isolate dose $10 \mathrm{~g}$ and $20 \mathrm{~g}$ per plant and in $30 \mathrm{~g}$ per plant, the infection percentage was 10\% [13]. In sorgum, the infection percentage was $10 \%-60 \%$ [14]. Low root infection percentage Jabon and sorgum if compared to potato due to in these plants, the food reserve was storage in stem so that the root exudate that was used by rhizobacteria was less.

Table 1:-Percentage of root infection of potato in interaction between rhizobacteria isolates and MA application in 9 weeks after planting (WEP) (\%)

\begin{tabular}{|l|c|c|c|}
\hline \multirow{2}{*}{ Rhizobacteria isolates } & \multicolumn{3}{|c|}{ Dose of MA } \\
\cline { 2 - 4 } & $5 \mathrm{~g} / \mathrm{plant}$ & $10 \mathrm{~g} / \mathrm{plant}$ & $15 \mathrm{~g} / \mathrm{plant}$ \\
\hline No rhizobacteria & 77 & 76 & 73 \\
\hline RZ1.L2.4 & 77 & 78 & 87 \\
\hline RZ1.L2.1 & 80 & 78 & 78 \\
\hline RZ2.L2.1 & 81 & 85 & \\
\hline $\begin{array}{l}\text { Coefficient of diversity } \\
(\%)=7.96\end{array}$ & & & \\
\hline
\end{tabular}

According the result, the growth rate of plant developed rapidly. The factors affected the percentage of root infection due to the suitability the experimental condition and growth condition and development of rhizobacteria and MA [15]. The experimental soil condition was andisol, a fertile soil contained high organic matter and has good structure, supported the plant growth. Moreover, the type of plant also significantly influenced the rhizobacteria and MA development. MA colonized and the food reserve was stored in potato root zone. It caused the rhizobacteria and MA obtained the nutrition in growth and development [16]. The result was proven by the microscopic observation of potato root (Figure 1). 

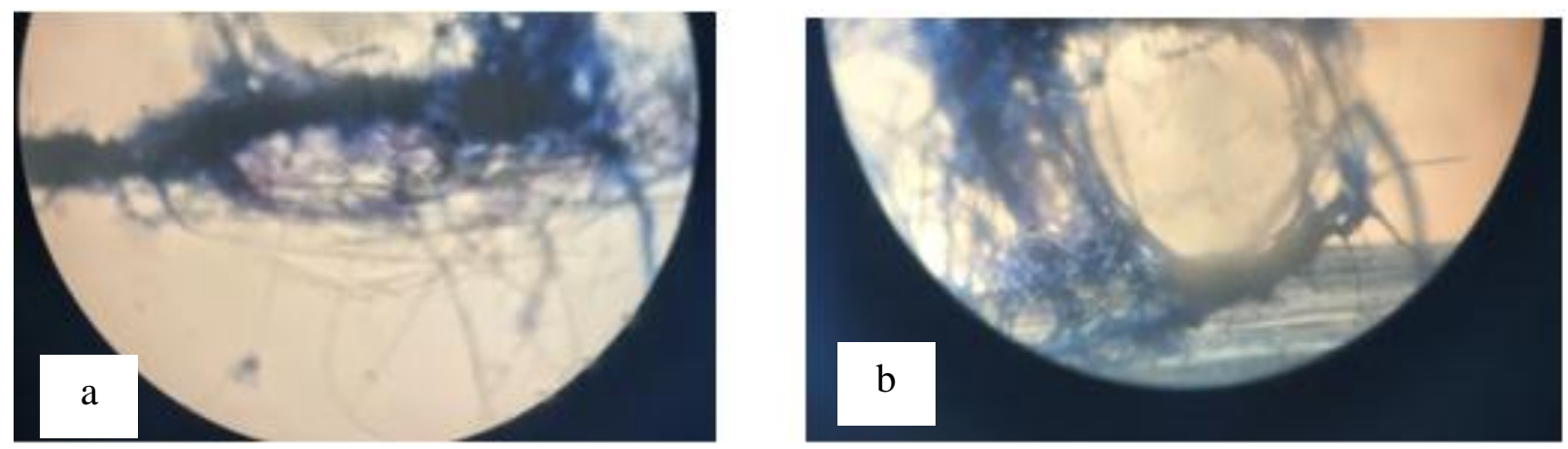

Figure 1:-Microscopic appearance of potato root infection : a) no rhizobacteria isolate and MA application in dose $5 \mathrm{~g} /$ plant. b) RZ2.L2.1 and MA application in dose $15 \mathrm{~g} / \mathrm{plant}$

Naturally, the microorganism lived in root zone of plant. The amount of them depended to type of plant. Several microorganism is mutualism related with plant. The plant provided the energy source and MA infected the plant root so that the availability of nutrients were available for plant. Higher infection of root, the plant growth was better. If host plant could support the growth and the development of plant, the dose of low of MA dose produced the similar result to the root that infected by high infection of isolates [17].

\section{Density of MA spores}

The highest density of MA spore in 9 WAP occured in RZ2.L2.1 isolate and MA dose 15 g (567). The lowest density occrued in RZ1.L2.1 and dose $5 \mathrm{~g}$ (Table 2). The rsult showed that higher dose of MA that was applied, the number of early inoculum was higher so that the growth and development of potato grew well. But, in certain condition, the development of MA was not only affected by number of early inoculum, but it was affected by other microorganisms that grew together in same area. One of microbes succes was their adaptation and colonizing the host plant root. If all isolates could colonize roots, the different result of plant was affected by activity of growth supporter of bacteria isolates [18]. In the assay, the factor affected the spore density of MA was other microbes that lived in potato root zone.

The MA application and rhizobacteria could incerase the degree of micorrhizal colonization in plant root by increasing the $\mathrm{P}$ availability by rhizobacteria. But, in several bacteria such as Paenibacillus polymyxa B1-B4 and Paenibacillus brasiliensis PB177, they did not affect the micorrhiza colonization degree [19]. Bacillus licheniformis CECT5106 and Bacillus pumulis CECT5105 could not incerase the degree of pine root colonization. The result described that the interaction between rhizobacteria and MA isolates was not synergistic for increasing the degree of micorrhiza colonization in plant root [18].

Table 2:-Density of MA spore in interaction between rhizobacteria isolates and MA application in 9 weeks after planting (WEP)

\begin{tabular}{|l|c|c|c|}
\hline \multirow{2}{*}{ Rhizobacteria isolates } & \multicolumn{3}{|c|}{ Dose of MA } \\
\cline { 2 - 4 } & $5 \mathrm{~g} / \mathrm{plant}$ & $10 \mathrm{~g} / \mathrm{plant}$ & $15 \mathrm{~g} / \mathrm{plant}$ \\
\hline No rhizobacteria & 245 & 393 & 273 \\
\hline RZ1.L2.4 & 142 & 298 & 175 \\
\hline RZ1.L2.1 & 225 & 248 & 345 \\
\hline RZ2.L2.1 & 409 & 178 & 567 \\
\hline
\end{tabular}

\section{Length of root}

Interaction between rhizobacteria isolates and AM affected the length of potato root. The result showed that no rhizobacteria and RZ1.L2.4 isolates with $10 \mathrm{~g} /$ plant of MA dose were best tratments for length of potato root. (Table 3). The result showed that the length of root was not only affected by MA dose, but it was affected by type of rhizobacteria. Certain rhizobacteria could increase length of root with addition of low MA dose. But, the length of root decreased if the dose of MA was increased [20]. The rhizobacteria and MA application did not always increase the length of root, but it incrased canopy growth]. The rhizosphere microorganisms that applied, roots were shorter due to they were active in addition of roots hairy and plant growth in soil surface [15]. 
Table 3:-Length of potato root in interaction between rhizobacteria isolates and MA application in 9 weeks after planting (WEP) $(\mathrm{cm})$

\begin{tabular}{|l|c|c|c|}
\hline \multirow{2}{*}{ Rhizobacteria isolates } & \multicolumn{3}{|c|}{ Dose of MA } \\
\cline { 2 - 4 } & $5 \mathrm{~g} / \mathrm{plant}$ & $10 \mathrm{~g} / \mathrm{plant}$ & $15 \mathrm{~g} / \mathrm{plant}$ \\
\hline No rhizobacteria & $21.90 \mathrm{~b}$ & $28.40 \mathrm{a}$ & $23.00 \mathrm{~b}$ \\
& $\mathrm{~B}$ & $\mathrm{~A}$ & $\mathrm{C}$ \\
\hline RZ1.L2.4 & $25.30 \mathrm{~b}$ & $29.93 \mathrm{a}$ & $27.90 \mathrm{a}$ \\
& $\mathrm{B}$ & $\mathrm{A}$ & $\mathrm{A}$ \\
\hline RZ1.L2.1 & $29.03 \mathrm{a}$ & $20.77 \mathrm{c}$ & $26.20 \mathrm{~b}$ \\
& $\mathrm{~A}$ & $\mathrm{C}$ & $\mathrm{B}$ \\
\hline RZ2.L2.1 & $20.10 \mathrm{~b}$ & $24.00 \mathrm{a}$ & $20.77 \mathrm{~b}$ \\
& $\mathrm{~B}$ & $\mathrm{~B}$ & $\mathrm{C}$ \\
\hline Coefficient of diversity & & & \\
$(\%)=3.14$ & & & \\
\hline
\end{tabular}

The similar uppercase and lower case are different significantly according DNMRT in 5\%

The result showed that potato plant had different response to MA and rhizobacteria isolates. Each rhizobacteria had different ability in increasing the nutrients absorption and growth so that the different effectiveness in increasing growth in the field. Moreover, the rhizobacteria and MA application maximized root hairy growth and increased nutrients availability if compared to addition of length of root. Root of plant played a essential function for plant growth. Root develompent and its ability to absorb nutrient incerased the growth and develompent of plant. Root had hairs for helping to absorb water and nutrients from soil. Longer roots produced more hairs and the water and nutrients absorption was optimal. Root development was also influenced by bacteria in rhizosphere such as Bacillus sp., a bacteria could dissolve phosphate so that could increase the $\mathrm{P}$ availability in soil and it was plant growth indicator [21].

Rhizobacteria also could increased the width of root surface per soil volume. The increasing of it was marked by addition of number of roots hairy and was not significantly affected by addition of root length [15]. Moreover, appropriate doses of MA significantly affected root length. $4 \mathrm{~g} /$ plant of MA dose did not still affect the root length so that the higher dose was required [22]. $7.5 \mathrm{~g} /$ plant of MA dose affected growth and yield of plant [23].

\section{Weight of root}

The interaction between rhizobacteria and MA dose affected weight of potato plant. The result showed that isolate RZ1.L2.4 and $15 \mathrm{~g} / \mathrm{plant}$ of MA dose and RZ1.L2.1 and $15 \mathrm{~g} / \mathrm{plant}$ of MA dose and RZ2.L2.1 and $10 \mathrm{~g} / \mathrm{plant}$ and 15 $\mathrm{g} / \mathrm{plant}$ of MA doses were the best treatments for weight of potato root (Table 4).

Table 4:-Weight of potato root in interaction between rhizobacteria isolates and MA application in 9 weeks after planting (WEP) $\left(\mathrm{mg} / \mathrm{cm}^{2} /\right.$ week)

\begin{tabular}{|l|c|c|c|}
\hline \multirow{2}{*}{ Rhizobacteria isolates } & \multicolumn{3}{|c|}{ Dose of MA } \\
\cline { 2 - 4 } & $5 \mathrm{~g} / \mathrm{plant}$ & $10 \mathrm{~g} / \mathrm{plant}$ & $15 \mathrm{~g} / \mathrm{plant}$ \\
\hline No rhizobacteria & $9.88 \mathrm{a}$ & $9.59 \mathrm{a}$ & $7.52 \mathrm{~b}$ \\
& $\mathrm{~B}$ & $\mathrm{BC}$ & $\mathrm{C}$ \\
\hline RZ1.L2.4 & $9.47 \mathrm{~b}$ & $8.12 \mathrm{~b}$ & $12.52 \mathrm{a}$ \\
& $\mathrm{B}$ & $\mathrm{C}$ & $\mathrm{A}$ \\
\hline RZ1.L2.1 & $13.56 \mathrm{a}$ & $10.54 \mathrm{~b}$ & $10.17 \mathrm{~b}$ \\
& $\mathrm{~A}$ & $\mathrm{~B}$ & $\mathrm{~B}$ \\
\hline RZ2.L2.1 & $10.19 \mathrm{~b}$ & $14.52 \mathrm{a}$ & $13.65 \mathrm{a}$ \\
& $\mathrm{B}$ & $\mathrm{A}$ & $\mathrm{A}$ \\
\hline Coefficient of diversity & & & \\
$(\%)=3.14$ & & & \\
\hline
\end{tabular}

The similar uppercase and lower case are different significantly according DNMRT in 5\%

The different result of root weight was caused by each rhizobactaria produced different exudate in types, number and different interaction with MA. Basically, all isolates produced plant stumulate hormones such as indole acetic 
acid (IAA), giberrellin, cytokinin and ethyline in root [24]. Presence of hormone activity that produced by rhizobacteria caused cell division process. If rhizobacteria produced much hormones, low MA dose could increase weight of root due to IAA was produced by rhizobacteria was enough for plant requirement to undergo cell division of root [25]. Rhizobacteria that produced low hormone, it needed MA much dose due to addition of MA dose increased $\mathrm{P}$ absorption was required by plant in hormone formation and protein for cell division of root [26].

Rhizobacteria affected the number of hormone due to each rhizobacteria produced different number of hormone. Meanwhile, MA affected number of P. Commonly, increasing of MA dose increased $\mathrm{P}$ availability. Certain rhizobacteria with low MA caused plant produced high root weight and in rhizobacteria application, weight of root was low eventhough dose of MA was high. Weight of plant root was significantly affected by root hairs and root hairs was significantly affected by auxin and cytokinin, ATP activity and P availability [24]. It was caused in cell division and cell differentiation required number of hormone, nutrients and enzymes. Root plant that infected by MA, the expansion of root was wider due to there was external hyphae that expanded in out of root. Hyphae that produced by MA also produces phosphatase enzyme and could catalyze phosporus complex hydrolysis that was not available to be soluble phosphorus and available for plant [15].

\section{Net assimilation rate (NAR)}

Net assimilation rate was the efficiency of photosynthesis in leaves in a community of cultivated plants. The higehst NAR was obtained in size of leaves that were obtained sunlight. The result showed that NAR value of no rhizobacteria and RZ2.L2.1 isolates with MA dose $5 \mathrm{~g} /$ plant application was better than MA dose 10 and $15 \mathrm{~g}$. NAR value of isolate RZ1.L2.4 with MA dose $15 \mathrm{~g}$ was better than $5 \mathrm{~g}$ and $10 \mathrm{~g}$ doses. The best treatments in no rhizobacteria was obtained in MA dose $5 \mathrm{~g}$, rhizobacteria RZ1.L2.4 and MA dose $15 \mathrm{~g}$ and RZ2.L2.1 and MA dose $5 \mathrm{~g}$. For MA application, NAR of MA dose $5 \mathrm{~g}$ and no rhizobacteria isolate was better than other treatments (Table $5)$.

Table 5:-Net assimilation rate of potato in interaction between rhizobacteria isolates and MA application in 9 weeks after planting (WEP) $\left(\mathrm{mg} / \mathrm{cm}^{2} /\right.$ week)

\begin{tabular}{|l|c|c|c|}
\hline \multirow{2}{*}{ Rhizobacteria isolates } & \multicolumn{3}{|c|}{ Dose of MA } \\
\cline { 2 - 4 } & $5 \mathrm{~g} / \mathrm{plant}$ & $10 \mathrm{~g} / \mathrm{plant}$ & $15 \mathrm{~g} / \mathrm{plant}$ \\
\hline No rhizobacteria & $0.00115 \mathrm{a}$ & $0.00018 \mathrm{~b}$ & $0.00017 \mathrm{~b}$ \\
& $\mathrm{~A}$ & $\mathrm{BC}$ & $\mathrm{AB}$ \\
\hline RZ1.L2.4 & $0.00015 \mathrm{~b}$ & $0.00014 \mathrm{~b}$ & $0.00016 \mathrm{a}$ \\
& $\mathrm{C}$ & $\mathrm{C}$ & $0.0001 \mathrm{~b}$ \\
& $0.0002 \mathrm{~b}$ & $0.0003 \mathrm{a}$ & $\mathrm{B}$ \\
\hline RZ1.L2.1 & $\mathrm{C}$ & $\mathrm{A}$ & $0.0003 \mathrm{~b}$ \\
& $0.0009 \mathrm{a}$ & $0.0004 \mathrm{~b}$ & $\mathrm{~A}$ \\
\hline Coefficient of diversity & $\mathrm{B}$ & $\mathrm{A}$ & \\
$(\%)=5.01$ & & & \\
\hline
\end{tabular}

The similar uppercase and lower case are different significantly according DNMRT in 5\%

Increasing of plant age caused the NAR value and the leaves that were not obtained the sunlight, the NAR value was low. The highest value of NAR in young leaves absorbed much sunlight, highest $\mathrm{CO} 2$ assimilation rate and distributing most of assimilate to other parts of plant [27]. Sunlight affected enzymes in plant. In appropriate temperature, plant enzymes stimulated plant growth so that the mass production and light was absorbed by leaves to undertake the photosynthesis increased. The photosynthate was produced by plant affected the plant growth so that it affected the NAR [28].

\section{Leaf area index (LAI)}

The result showed that rhizobacteria isolate dose affected the leaf area index of potato. The result described no rhizobacteria isolate and $5 \mathrm{~g} / \mathrm{plant}$ of MA dose and also isolate RZ2.L2.1 and $15 \mathrm{~g} / \mathrm{plant}$ of MA dose were the best treatments for leaf area index (Table 6). 
Table 6:-Leaf area index of potato in interaction between rhizobacteria isolates and MA application in 9 weeks after planting (WEP) $\left(\mathrm{mg} / \mathrm{cm}^{2} /\right.$ week)

\begin{tabular}{|l|c|c|c|}
\hline \multirow{2}{*}{ Rhizobacteria isolates } & \multicolumn{3}{|c|}{ Dose of MA } \\
\cline { 2 - 4 } & $5 \mathrm{~g} / \mathrm{plant}$ & $10 \mathrm{~g} / \mathrm{plant}$ & $15 \mathrm{~g} / \mathrm{plant}$ \\
\hline No rhizobacteria & $0.03093 \mathrm{a}$ & $0.00808 \mathrm{~b}$ & $0.01061 \mathrm{~b}$ \\
& $\mathrm{~B}$ & $\mathrm{D}$ & $\mathrm{C}$ \\
\hline RZ1.L2.4 & $0.01060 \mathrm{~b}$ & $0.01637 \mathrm{a}$ & $0.00523 \mathrm{c}$ \\
& $\mathrm{C}$ & $\mathrm{C}$ & $\mathrm{D}$ \\
\hline RZ1.L2.1 & $0.0128 \mathrm{~b}$ & $0.0315 \mathrm{a}$ & $0.0360 \mathrm{a}$ \\
& $\mathrm{C}$ & $\mathrm{A}$ & $\mathrm{A}$ \\
\hline RZ2.L2.1 & $0.0465 \mathrm{a}$ & $0.0272 \mathrm{~b}$ & $0.0200 \mathrm{c}$ \\
& $\mathrm{A}$ & $\mathrm{B}$ & $\mathrm{B}$ \\
\hline Coefficient of diversity & & & \\
$(\%)=5.29$ & & & \\
\hline
\end{tabular}

The similar uppercase and lower case are different significantly according DNMRT in 5\%

According the result, the response of isolates and MA dose was different. Each isolates of rhizobacteria had certain characteristic. These best treatments had higher ability for supporting plant leaves growth. If related to correlation between rhizobacteria and MA factor, there was posstive correlation between number of leaves and LAI . The result was appropriate to definition of LAI. Lai was ratio between width of leaf and width of soil area that overgrown potato plants. One of factor that significantly affected LAI value was number of leaves. More number of leaves and wider leaves had higher LAI value [28].

Increasing of LAI posstively contributed to plant growth due to leaves were main organ that played role as photosynthesis place occured. Distribution of sunlight also played important role for increasing of LAI value. LAI value in most of plants was 0 and for few weeks later, it could be under 1.0 and furthermore increased quickly until maximum. This condition variously occured in plants and environment [27]. Wider leaves usually was remained until mature except the leaves were disrupted by pests and diseases [7].

\section{Conclusion:-}

The best treatment of the assay was RZ2.L2.1 and $5 \mathrm{~g} / \mathrm{plant}$ of MA dose for potato growth.

\section{References:-}

1. Whitworth JL, Selstedt RA, Westra AAG, Nolte P, Duellman K, Yellareddyagari SKR, Gudmestad NC. 2019. Symptom expression of mainstream and specialty potato cultivars to bacterial ring root (Clavibacter sepedonicus) and evaluation of in-field detection. American Journal of Potato Reserach. 96 (4): 427-444

2. Beals KA. 2018. Potato, nutrition and health. Americal Journal of Potato Research. 96: 102-110

3. Food and Agricultural Organization. 2014. http://faostat3.fao.org

4. Gange AC, Gadhave KR. 2018. Plant growth promoting rhizobacteria promote plant size inequality. Scientific Reports. 8: 1-10

5. Ahemad M, Kibret M. 2013. Mechanism and applications of plant growth promoting rhizobacteria: Current perspective. Journal of King Saudi Univeristy. 26: 1-20

6. Gunez A, Karagoz K, Turan M, Kotan R, Yildrim E, Cakmakci R, Shain F. 2015. Fertilizer efficiency of some plant growth promoting rhizobacteria for plant growth. Reserach Journal of Soil Biology. 7(2): 28-45

7. Vessey JK. 2003. Plant growth promoting rhizobacteria as biofertilizers. Plant and soil. 225(2): 571-586

8. Passos JFM, Costa PB, Costa MD, Zaffari GR, Nava G, Boneti JI, Oliveira AMR, Passaglia LMP. 2014. Cultivable bacteria isolated from apple trees cultivated under different crop system: Diversity and antagonistic activity against Colletotrichum gloeosprioides . Genetics and Molecular Biology. 37(3): 560-572

9. Wahyudi AT, Priyanto JA, Afrista R, Kurniawati D, Astusti RI, Akhdiya A. 2019. Plant growth promoting activity of Actinomycetes isolated from soybean rhizosphere. Journal of Biological Science. 19(1): 1-8

10. Wang H, Li H, Zhang M, Song Y, Huang J, Huang H, Shao M, Liu Y. 2018. Carbon dotd enhance the nitrogen fixation activity of Azetobacter chrococcum. Applied Materials and Interfaces. 10(19): 16308-15314

11. Nusantara AD, Bertham YH, Mansur I. 2012. Working with arbuscular mycorrhiza. Seameo Biotrop. 82

12. Puspitasari D, Purwani KI, Muhibuddin A. 2012. Exploration of indigenous vesicular arbuscular mycorrhiza on corn field, Sampang, Madura, East Java. Journal of Science and Art. 1: 19-22 
13. Adelina MH. 2018. Effect of mycorrhiza dose application to growth of Jabon (Anthocephalus cadamba) in allelopathy compound. Thesis. North Sumatera University.

14. Widawati S, Suliasih. 2018. The Effect of Plant Growth Promoting Rhizobacteria (PGPR) on Germination and Seedling Growth of Sorghum bicolor L. Moench. Proceeding of Earth and Environmental Science. 1-10

15. Rillig MC, Mummey DL. 2006. Mycorrhizas and soil structure. New Phytopathology. 171: 41-53

16. Smith SE, Read DJ. 2008. Mycorrhizal symbiosis. $3^{\text {rd }}$ edition. San Diego. Academic Press

17. Yolcu H, Turan M, Lithourgidis A, Cakmakci R, Koc A. 2011. Effect of plant growth promoting rhizobacteria and manure on yield and quality characteristic of Italian ryegrass under semi arid condition. Australian Journal of Crop Science. 5(13): 1730-1736

18. Vogelsang KM, Bever JD. 2009. Mycorrhizal densities declibe in association with non-active plants and contribute to plant invasion. Journal of Ecology. 90: 399-407

19. Lorentz RH, Artico S, Silviera AB, Einsfeld A, Corcao G. 2006. Evaluation of antimicrobial activity in Paenibacillus spp. strains isolated from natural environment. Letters in Applied Microbiology. 43: 541-547

20. Chen MM, Yin HB, O'Connor P, Wang YS, Zhu YG. 2010. C:N:P stoichiometry and specific growth rate of clover colonized by arbuscular mycorrhizal fungi. Plant Soil. 326: 21-29

21. Phandey C, Bajpai YK, Negi YK, Rather LA, Maheswari DK. 2018. Effcet of plant growth promoting Bacillus spp. On nutritional properties of Amaranthus hypochondriacus grains. Saudi Journal of Biological Science. 25(6): 1066-1071

22. Kuswandi P, Sugiyarto L. 2015. Mycorrhiza application in palnting medium of 2 tomato varieties to increase productivity in drought stress. Basic Science. 4(1): 17-22

23. Sukmawati E, Hafsan, Hasriani. 2016. Identification of arbuscular mycorriza fungi from culrivated plant roots. Biogenesis. 4(1): 16-20

24. Karnwal A. 2009. Production of indole acetic acid by flourescent Pseudomonas in the presence of LTryptophan and rice root exudate. Journal of Plant Pathology. 91(1): 61-63

25. Jayasudha T, Rangeshwaran R, Vajid NV. 2010. Relatiosnhip between indole acetic acid production by flourescent Pesudomonas and plant growth promotion. Journal of Biological Control. 24(4): 349-359

26. Li M, Guo R, Yu F, Chen H, Zhao H, Li H, Wu J. 2018. Indole-3-acetic acid biosynthesis pathways in the plant beneficial bacterium Arthrobacter pascens ZZ21. Interanstional Journal of Molecular Science. 19(2): 443

27. Fitter AH, Hay RKM. 1994. Physiology of plant enviroments. University Press. Yogyakarta

28. Gardnerr FP, Peace RB, Micthell RL. 1991. Physiology of cultivated plants. University of Indonesia Press. Jakarta. 428 p. 